\title{
Variation of selected morphological characters of the cave mite Oribella cavatica Kunst, 1962 (Acari, Oribatida)
}

\author{
KRYSTYNA ŻBIKOWSKA-ZDUN ${ }^{1}$, KRZYSZTOF PIKSA² and ANNA SMACZYŃSKA
}

Department of Invertebrate Zoology and Parasitology, Institute of Biology, Pedagogical University of Cracow, Podbrzezie 3, 31-054 Kraków, Poland; e-mail: 'kmzdun@interia.pl, ${ }^{2 k r z y c h u @ a p . k r a k o w . p l ~}$

(Received on 15 April 2008; Accepted on 19 October 2009)

\begin{abstract}
Two populations of Oribella cavatica were examined. The mites were isolated from bat guano collected in February 2006 in Zbójecka Cave in Mount Łopień and in the cave Czarci Dół, which are situated in the Beskid Wyspowy Mountains, within the Flysch Carpathians in southern Poland. Coefficients of variation of body length and width, lamella length, and sensillus length of this species under stenotopic conditions were compared with those of two eurytopic species. The stable variation of sensillus length of O. cavatica, like differences in the variation of Heminothrus peltifer in various soil habitats, may have bioindicative significance.
\end{abstract}

Keywords: morphological variation, Oribatida, bioindication, cave

\section{INTRODUCTION}

Oribella cavatica is a mite species that was first isolated from the guano of bats living in the cave Čertova diera in northern Slovakia (Kunst 1962). In Poland this species has been found in caves in the vicinity of Ojców (southern Poland) (RAFALSKI 1977). Apart from caves, the species has been found in burrows of marmots (RAFALSKI 1977) and in the soil under mosses near the village of Kryłów, on the river Bug (ŻBIKOWSKA-ZDUN et al. 2006).

Its distribution practically limited to caves allows us to include this oribatid mite among troglophiles or troglobites. However, the species does not have troglomorphic features, like those noticed in the Brachychtoniidae and the Oppioidea, which occur most frequently in caves and in habitats with similar environmental conditions (e.g. mines) (SkubaŁa \& KŁYs 2002, Ducarme et al. 2000, 2003).

We have found in our research $O$. cavatica to be extremely numerous in guano samples, which seems to indicate that it is a coprophilous or guanophilous species (c.f. Kunst 1962, Palacios-Vargas et al. 1998), and optimal stenotopic ecological conditions favour the development of its large populations. Similar ecological conditions, though not so stable, prevail in the pores of humid soil. 
An assessment of variation of a species living in caves under stable stenotopic conditions may be helpful in interpreting the variation of other species living under eurytopic conditions and in answering the question posed in bioindication studies, whether the variation among individuals is a result of genetic or environmental differences (KRZANOWSKA et al. 2002).

The aim of our study was to examine selected morphometric features of $O$. cavatica living in stenotopic conditions and to compare them with the variation of two earlier examined eurytopic species: Heminothrus peltifer (C.L. KocH, 1839) and Achipteria coleoptrata (Linnaeus, 1758) (ŻBikOWSKA-Zdun \& WoŁeK 2006).

\section{MATERIAL AND METHODS}

The research was carried out in two caves:

(1) Zbójecka Cave in Mount Łopień $\left(20^{\circ} 17^{\prime} \mathrm{E}, 49^{\circ} 42^{\prime} \mathrm{N}\right)$ - with 3 entrances situated at the altitude of about $880 \mathrm{~m}$; known corridor about $430 \mathrm{~m}$ long, denivelation $16 \mathrm{~m}$;

(2) Czarci Dół $\left(20^{\circ} 16^{\prime} \mathrm{E}, 49^{\circ} 42^{\prime} \mathrm{N}\right)$ - with an entrance situated at an altitude of about $770 \mathrm{~m}$; known corridors about $140 \mathrm{~m}$ long, denivelation $14 \mathrm{~m}$.

The described localities lie in southern Poland, in the Beskid Wyspowy Mountains within the Flysch Carpathians, on the northern slope of Mount Łopien. They are typical pseudokarst caves. Climatic conditions in the caves are stable (relative humidity above $90 \%$, air temperature $7-12^{\circ} \mathrm{C}$ ). Organic matter (guano of bats) is found in those caves. Bats stay in caves all the year round. They are large winter quarters of Rhinolophus hipposideros in Poland. A winter colony of this species in Zbójecka Cave in Łopień counts about 500 individuals and in Czarci Dół about 120 individuals (the count surveys were conducted in the middle of the winter seasons i.e. in February). Furthermore, members of other bat species have been observed hibernating in caves, but their numbers have not exceeded several individuals (PIKSA, unpubl. results).

The mites from 10 samples of bat guano collected from the cave floor in February 2006 were isolated with a standard method, using the Tullgren funnel. Each sample was about $220 \mathrm{~cm}^{3}$ in volume. Among the collected mites, the most numerous was O. cavatica (about 1500 specimens in total). Besides, a few oribatid mites from the families Hypochthoiidae and the Oppiidae were found, as well as the Scutacaridae, which were abundant.

To analyse the variation, the following morphological features were chosen: body length and width, lamella length, and sensillus length. In total, 800 measurements on 200 mature specimens of $O$. cavatica (95 from Zbójecka Cave in Mount Łopień and 105 from cave Czarci Dół) were made and statistically analysed.

\section{RESULTS AND DISCUSSION}

Oribella cavatica belongs to the suborder Brachypylina and its cerotegument is light brown, fairly strongly sclerotized, with lamellae strengthening it on the prodorsum. These are not features typical for troglobionts. Mites of this species living 
in caves differ from those living in the soil in their morphometric features, such as body length and width, leg length, as well as the shape and length of various setae and the sensillus. Troglomorphic features of cave mite species include larger body size and longer sensilli (DuCARME et al. 2004). Those authors, however, did not study the variability of the above-mentioned features for particular species. It is well known that the mites living in humid soil have longer sensilli (AOKI 1973). The investigated populations of $O$. cavatica were fairly uniform and similar to each other (Tables 1 and 2). According to the literature, its body length is $420-500 \mu \mathrm{m}$ (WEIGMANN 2006), but the mites examined in this study were slightly smaller, 372-453 $\mu \mathrm{m}$ long (Tables 1 and 2). Only $30 \%$ of the examined mites were over $420 \mu \mathrm{m}$ long. This seems to be connected with the size dynamics of the studied population, with nearly unlimited access to the nutients from bat guano. The mean length of a specimen from Zbójecka Cave in Łopień was $411.60 \mu \mathrm{m}$, whereas at Czarci Dół it was $408.05 \mu \mathrm{m}$. Other statistics also show great similarity of both populations. Additionally, the variation of body size (length and width) in both caves was similar (Tables 1 and 2).

Table 1. Arithmetic mean, standard deviation (SD), minimum (Min.) and maximum value (Max.), and coefficient of variation (CV) of selected morphological features of adults of Oribella cavatica collected in Zbójecka Cave in Łopień

\begin{tabular}{lrrrrr}
\hline Feature & Mean $(\mu \mathrm{m})$ & $\mathrm{SD}(\mu \mathrm{m})$ & Min. $(\mu \mathrm{m})$ & Max. $(\mu \mathrm{m})$ & $\mathrm{CV}$ \\
\hline Body length & 411.60 & 18.52 & 372.3 & 452.9 & 0.045 \\
Body width & 248.97 & 16.93 & 209.1 & 290.7 & 0.068 \\
Sensillus length & 74.43 & 7.89 & 56.1 & 107.1 & 0.106 \\
Lamella length & 76.94 & 7.54 & 56.1 & 91.8 & 0.098 \\
\hline
\end{tabular}

Table 2. Arithmetic mean, standard deviation (SD), minimum (Min.) and maximum value (Max.), and coefficient of variation (CV) of selected morphological features of adults of Oribella cavatica collected in Czarci Dół

\begin{tabular}{lrrrrr}
\hline Feature & Mean $(\mu \mathrm{m})$ & $\mathrm{SD}(\mu \mathrm{m})$ & Min. $(\mu \mathrm{m})$ & Max. $(\mu \mathrm{m})$ & $\mathrm{CV}$ \\
\hline Body length & 408.05 & 16.24 & 336.6 & 453.9 & 0.039 \\
Body width & 244.00 & 14.64 & 204.0 & 280.5 & 0.060 \\
Sensillus length & 75.37 & 8.14 & 51.0 & 112.2 & 0.108 \\
Lamella length & 75.05 & 6.98 & 56.1 & 91.8 & 0.093 \\
\hline
\end{tabular}

Coefficients of variation of the measurable features of $O$. cavatica living under stenotopic conditions and two eurytopic species Heminothrus peltifer and Achipteria coleoptrata (ŻBIKOWSKA-ZDUN \& WoŁEK 2006). are compared in Table 3 . The varia- 
Table 3. Coefficients of variation of selected measurable characters of adults of Oribella cavatica in this study, compared to those of Heminothrus peltifer and Achipteria coleoptrata (ŻBIKowsKAZdUN \& WoŁeK 2006)

\begin{tabular}{lcccc}
\hline & \multicolumn{4}{c}{ Coefficient of variation } \\
\cline { 2 - 5 } Species and site & $\begin{array}{c}\text { body } \\
\text { length }\end{array}$ & $\begin{array}{c}\text { body } \\
\text { width }\end{array}$ & $\begin{array}{c}\text { sensillus } \\
\text { length }\end{array}$ & $\begin{array}{c}\text { lamella } \\
\text { length }\end{array}$ \\
\hline $\begin{array}{l}\text { Oribella cavatica } \\
\text { Zbójecka Cave } \\
\begin{array}{l}\text { Oribella cavatica } \\
\text { Czarci Dół }\end{array}\end{array}$ & 0.05 & 0.07 & 0.11 & 0.10 \\
$\begin{array}{l}\text { Heminothrus peltifer } \\
\text { Meadow }\end{array}$ & 0.04 & 0.06 & 0.11 & 0.09 \\
$\begin{array}{l}\text { Heminothrus peltifer } \\
\text { Dump }\end{array}$ & 0.03 & 0.04 & 0.18 & $\mathrm{ND}$ \\
$\begin{array}{l}\text { Achipteria coleoptrata } \\
\text { Meadow }\end{array}$ & 0.04 & 0.06 & 0.29 & $\mathrm{ND}$ \\
$\begin{array}{l}\text { Achipteria coleoptrata } \\
\text { Dump }\end{array}$ & 0.05 & 0.08 & $\mathrm{ND}$ & $\mathrm{ND}$ \\
\hline
\end{tabular}

$\mathrm{ND}=$ difficult to measure or lack of feature

tion in body length and width is similar in all the species, irrespective of the type of habitat. Sensilli and lamellae in $O$. cavatica are characterised by relatively high variation, nearly identical in both caves. The eurytopic $H$. peltifer is characterised by the largest variation of the sensillus; a large difference in coefficient of variation between individuals living in soil and in a dump has also been noticed.

The compared results indicate that the only morphological feature whose variation may have a bioindicative significance is sensillus length. The variation of the sclerotized lamellae may also have bioindicative significance, but to prove it is necessary to compare the variation of the lamellae in eurytopic soil species. DuBININA \& Alekseev (1994) and Fujikawa $(1995,1999)$ found in their studies on the eurytopic species Tectocepheus velatus (Michael, 1880) and Oppiella nova (Oudemans, 1902) an effect of various environmental factors, including anthropogenic ones, on the length variation of the sensillus and sclerotized lamellae on the body. Those authors observed differences in the shape of the sensillus and the sclerotized lamellae on the prodorsum in populations inhabiting different habitats.

The species $O$. cavatica and the earlier examined $H$. peltifer have sensilli in the shape of straight setae, which are easy to measure. The stable variation of sensillus length in $O$. cavatica from different caves and significant variation of the same feature of the $H$. peltifer from various soils displays a bioindicative value.

Research on the bioindicative role of Oribatida is focused mainly on changes in the species diversity and dominance structure of oribatid mite communities (SENICZaK 1979, Skubala 1997, Straalen 1998). The results of our research show that the variation of selected morphometric features may play a similar role. 


\section{REFERENCES}

AокI J. 1973. Soil mites (Oribatida) climbing trees. In: Proceedings of the 3rd International Congress on Acarology, 31 August-6 September 1971, Prague, Czech Republic (Milan, D., RosICKÝ, B., Eds), pp. 59-65, Czechoslovak Academy of Sciences, Prague.

Dubinina H. V., Alekseev A. N.1994. Skeleton changes in the oribatid mites under the influence of the heavy metal ions accumulation. Acarina 2: 81-93.

Ducarme X., Wauthy G., Lebrun Ph. 2000. Cave terrestrial Oribatid mites in Europe. In: Program, Abstracts and list of participants of the $4^{\text {th }}$ Symposium of European Association of Acarologists, 24-28 July 2000, Siena, Italy (Universita degli Studi di Siena ed.), pp. 42.

Ducarme X., Michael G., Lebrun Ph. 2003. Mites from Belgian caves: an extensive study. Subter. Biol. 1: 13-23.

Ducarme X., Wauthy G., Andre H., Lebrun Ph. 2004. Survey of mites in caves and deep soil and evolution of mites in these habitats. Can. J. Zool. 82: 841-850.

Fujikawa T. 1995. Comparison among Populations of Tectocepheus velatus (Michael, 1880) from Forests Grasslands and Crop Field. Edaphologia 55:1-39.

Fusikawa T. 1999. Individual variations of two Reared Oribatid Species, Tectocepheus velatus (Michael,1880) and Oppiella nova (Oudemans,1902). Edaphologia 62:11-46.

Krzanowska H., Łomnicki A., Rafiński., Szarski H., Szymura J. M. 2002. Zarys mechanizmów ewolucji. [An Outline of Evolution Mechanisms] 415 pp., PWN, Warszawa.

Kunst M. 1962. Oribella cavatica n. sp. eine neue Moosmilbe aus dem guano der Fledermäuse (Acarina, Oribatei). Acta Univ. Carolinae-Biologica suppl. 1-6

Palacios-Vargas J.G., Decu V., Iavorski V., Hutzu M., Juberthie C. 1998. Acari terrestria. In: Encyclopaedia Biospeologica (Juberthie, C. Decu, V. Eds), pp. 929-952, Vol. III, Societe de Biospeologie, Moulis-Bucarest.

Rafalski J. 1977. Pajęczaki [Arachnida]. In: Przyroda Ojcowskiego Parku Narodowego [Nature of the Ojców National Park] (Zabierowski, K., Ed), pp. 335-340, Stud. Nat. Ser. B. PWN, Zakład Ochrony Przyrody, Warszawa, Kraków.

SENICZAK S. 1979. Fauna mechowców (Acari,Oribatei) jako indykator biologicznych właściwości próchnic leśnych. [ Moss mites (Acari, Oribatei) as indicator of biological properties of forest humus] Prace Kom. Nauk. 37:157-165.

Skubata P. 1997. The structure of oribatid mites communities (Acari,Oribatida) on mine dumps and reclaimed land. Zool. Beitr. NF. 38: 50-80.

SkubaŁa P., KŁys G. 2002. Oribatid fauna (Acari: Oribatida) in the mine underground workings. In: Postępy polskiej akarologii [Progress in Polish Acarology] (Ignatowicz S., Ed), pp. 203-212, SGGW, Warszawa.

StraAlen N. M. VAN. 1998. Evaluation of bioindicator systems derived from soil arthropod communities. Appl. Soil. Ecol. 9: 429-437.

Weigmann G. 2006. Hornmilben (Oribatida) In: Dahl, Die Tierwelt Deutschlands, 76. 520 pp., Verlag Goecke \& Evers, Keltern.

ŻBikowsKa-Zdun K., WoŁeK J. 2006. Morphological varation in Heminothrus peltifer (C. L. Koch, 1839) and Achipteria coleoptrata (Linnaeus, 1758) (Acari, Oribatida) occurring on natural and initial soil. In: Postępy polskiej akarologii [Progress in Polish Acarology] (IgNAtowicz S., Ed) pp. 477-484, SGGW, Warszawa.

Żbikowska-Zdun K., Piksa K., Watrak I. 2006. Diversity of mites (Acari: Oribatida) in selected microhabitats of the Bug River Protected Landscape Area. Biological Lett. 43: 277-286. 